\title{
Field Evaluation of Cucurbita Germplasm for Resistance to Whiteflies and Whitefly-transmitted Viruses
}

\author{
Alexander Luckew \\ Department of Horticulture, University of Georgia, Athens, GA 30602
}

\section{Geoffrey Meru}

Horticultural Sciences Department, University of Florida, Gainesville, FL 32611; and Tropical Research and Education Center, University of Florida, Gainesville, FL 32611

Ya-Ying Wang and Rodrick Mwatuwa

Horticultural Sciences Department, University of Florida, Gainesville, FL 32611

Mathews Paret and Renato Carvalho

Department of Plant Pathology, University of Florida, Gainesville, FL 32611

Melanie Kalischuk

Department of Plant Pathology, University of Florida, Gainesville, FL 32611; and Department of Plant Agriculture, University of Guelph, Guelph, Ontario N1G 2W1, Canada

Andre Luiz Biscaia Ribeiro da Silva

Department of Horticulture, University of Georgia, Athens, GA 30602; and Department of Horticulture, Auburn University, Auburn, AL 36849

Joara Candian

Department of Horticulture, University of Georgia, Athens, GA 30602

Bhabesh Dutta
Department of Plant Pathology, University of Georgia, Athens, GA 30602

Rajagopalbabu Srinivasan and Saritha Raman Kavalappara

Department of Entomology, University of Georgia, Athens, GA 30602

RRD Naga Charan Konakalla and Sudeep Bag

Department of Plant Pathology, University of Georgia, Athens, GA 30602

Cecilia McGregor

Department of Horticulture, University of Georgia, Athens, GA 30602

Additional index words. Cucurbit leaf crumple virus, CuLCrV, Cucurbit yellow stunting disorder virus, CYSDV, squash

Abstract. Summer squash (Cucurbita pepo L.) is a major vegetable crop produced in Georgia and Florida during the fall season. This production is vulnerable to whitefly (Bemisisia tabaci Genn.)-transmitted viruses that lead to severe yield losses. Over the past several years, whitefly populations have increased during the fall, thus leading to an increase in whitefly-transmitted viruses such as Cucurbit leaf crumple virus (CuLCrV) and Cucurbit yellow stunting disorder virus (CYSDV). Whitefly management for summer squash relies on the use of insecticides and can be costly without providing adequate management of the viruses. Deployment of host resistance to whiteflies and their transmitted viruses (CuLCrV and CYSDV) is the best strategy for mitigating yield loss of summer squash; however, no resistant cultivars are commercially available. In the current study, resistance or tolerance to whiteflies, CuLCrV, and CYSDV was determined for squash germplasm from the U.S. Department of Agriculture (USDA) Germplasm Resources Information Network (GRIN), university breeding programs, and commercial companies in Georgia and Florida across 2 years. In both locations and years, visual virus symptom severity scores were collected and a quantitative polymerase chain reaction (qPCR) was used to determine the CuLCrV viral load and CYSDV presence in Georgia. Whitefly-induced feeding damage was evaluated by directly assessing the intensity of silverleaf symptoms and visual counts of whitefly adults on the foliage in the field or in photographs. Virus symptom severity was lower in $C$. moschata Duchesne ex Poir. genotypes, namely, PI 550689, PI 550692, PI 550694, PI 653064, and Squash Betternut 900, than in other evaluated genotypes. Two $C$. pepo accessions were common between both locations for viral severity (PI 442294) or viral severity and viral load (PI 171625). Lower CuLCrV loads were identified in C. ecuadorensis Cutler \& Whitaker (PI 540895), and C. okeechobeensis (Small) L.H.Bailey (PI 540900) than other evaluated genotypes. Four genotypes tested negative for CYSDV during both years: $C$. pepo (PI 507882), C. moschata (PI 483345), C. ecuadorensis (PI 390455), and C. okeechobeensis (PI 540900); they are potential sources of resistance. Six $C$. moschata accessions (PI 211999, PI 550690, PI 550692, PI 550694, PI 634982, and PI 653064) showed high tolerance to silverleaf disorder and had the lowest adult whitefly counts. Collectively, the accessions identified in the current study are potential sources of resistance or tolerance to whitefly and whitefly-transmitted viruses (CuLCrV and CYSDV). 
Summer squash, including yellow squash and zucchini, are a major vegetable produced in the southeastern United States. In 2019, 7.1 million pounds of summer squash valued at $\$ 219.9$ million were grown on 43,500 acres in the United States (USDA, 2020). In Georgia, yellow squash and zucchini were valued at $\$ 63.5$ million across 6391 acres planted in 2019 (Stubbs, 2020). The most recent data from Florida indicated that $\$ 29.7$ million of squash was produced in 2017 (Florida Department of Agriculture, 2021). Unfortunately, cucurbit production is threatened by pests and plant pathogens in the southeastern United States, such as whiteflies and their transmitted viruses. Particularly, it is estimated that whiteflies and whiteflytransmitted viruses in Georgia were responsible for yield reductions of $35 \%$ and $15 \%$ in 2017 and 2018, respectively (Little et al., 2019, 2020).

The silverleaf whitefly, Bemisia tabaci (Gennadius), is an insect pest that feeds directly on the phloem of the plant. The feeding process not only reduces the plant vigor by reducing the plant sap but also allows the transmission of plant viral pathogens and other disorders such as silverleaf. The $B$. tabaci has a large host range that includes squash, tomato (Solanum lycopersicum L.), cotton (Gossypium hirsutum L.), tobacco (Nicotiana tabacum L.) and common beans (Phaseolus vulgaris L.). Efforts to manage whiteflies usually rely on weekly applications of insecticides that often result in minimal control when the insect population is high (Nakhla and Maxwell, 1998). As of 2020, four whitefly-transmitted viruses have been detected in Cucurbits in Georgia and Florida: $\mathrm{CuLCrV}, \mathrm{CYSDV}$, Squash vein yellowing virus (SqVYV), and Cucurbit chlorotic yellows virus (CCYV) (Adkins et al., 2011; Gadhave et al., 2018; Jailani et al., 2021; Kavalappara et al., 2021b).

The $\mathrm{CuLCrV}$ is a species in the genus Begomovirus and family Geminiviridae. Although $\mathrm{CuLCrV}$ was first detected in Florida and Georgia in 2006 and 2008, respectively, (Akad et al., 2008; Larsen and Kmiecik, 2010) epidemics resulting in significant economic losses have become common only recently (Gadhave et al., 2018). The $\mathrm{CuLCrV}$ has a single-strand DNA genome and is bipartite, with symptoms including yellowing and leaf crumpling or curling (Hagen et al., 2008). The CYSDV was first detected

Received for publication 11 Aug. 2021. Accepted for publication 4 Nov. 2021.

Published online 20 January 2022.

This study was partly funded by the USDAUGA Cooperative Agreement (58-6080-9-006 "Managing whiteflies and whitefly-transmitted viruses in vegetable crops in the southeastern U.S.") and the Florida Department of Agriculture and Consumer Services (grant \#025801).

C.M. is the corresponding author. E-mail: cmcgre1@uga.edu.

This is an open access article distributed under the CC BY-NC-ND license (https://creativecommons. org/licenses/by-nc-nd/4.0/).

Table 1. Analysis of variance of area under the disease progress curve calculated from viral symptom severity at the Tifton, GA, and Live Oak, FL, locations.

\begin{tabular}{|c|c|c|c|c|}
\hline & df & MS & $F$ value & $\operatorname{Pr}>F$ \\
\hline \multicolumn{5}{|c|}{ Tifton, GA } \\
\hline Year & 1 & $6,058,229$ & 29.944 & $<0.0001$ \\
\hline Replication & 2 & 464,346 & 2.295 & 0.1020 \\
\hline Year $\times$ genotype & 186 & 316,550 & 1.565 & $<0.0001$ \\
\hline Genotype & 219 & 475,965 & 2.353 & $<0.0001$ \\
\hline Residuals & 539 & 202,319 & & \\
\hline \multicolumn{5}{|c|}{ Live Oak, FL } \\
\hline Year & 1 & 805 & 0.002 & 0.9681 \\
\hline Replication & 2 & $2,504,265$ & 4.966 & 0.0072 \\
\hline Year $\times$ genotype & 169 & 918,327 & 1.821 & $<0.0001$ \\
\hline Genotype & 199 & 884,531 & 1.754 & $<0.0001$ \\
\hline Residuals & 732 & 504,262 & & \\
\hline
\end{tabular}

in Florida in 2007 (Polston et al., 2008), and in Georgia in 2016 (Gadhave et al., 2018). The CYSDV is a species in the genus Crinivirus and family Closteroviridae. The CYSDV genome includes two positive-sense single-strand RNA segments (Aguilar et al., 2003; Marco and Aranda, 2005; Rubio et al., 2001). Symptoms of CYSDV include chlorotic spots on older leaves that lead to interveinal chlorosis, brittle leaves, upward rolling of leaves, and stunting. The CCYV is also a species in the genus Crinivirus and produces foliar symptoms similar to those of CYSDV (Kavalappara et al., 2021b). The SqVYV is a species in the genus Ipomovirus and family Potyviridae. The SqVYV has a linear positive-sense single-strand RNA segment and produces yellow veins on the infected plants (Adkins et al., 2007). The CuLCrV is transmitted by whiteflies in a persistent and nonpropagative manner (Czosnek et al., 2002), whereas all the other three viruses are transmitted semi-persistently by whiteflies (NavasCastillo et al., 2011).

The host range of both CCYV and SqVYV is limited to Cucurbitaceae (Adkins et al., 2007). In contrast, CYSDV and $\mathrm{CuLCrV}$ can infect crops and weeds in other families, including Asteraceae, Fabaceae, and Solanaceae (Adkins et al., 2009; Wintermantel et al., 2009). Additionally, the CYSDV and $\mathrm{CuLCrV}$ are often found as a mixed infection, leading to an increase in symptom severity (Gautam et al., 2020). The wide host

A

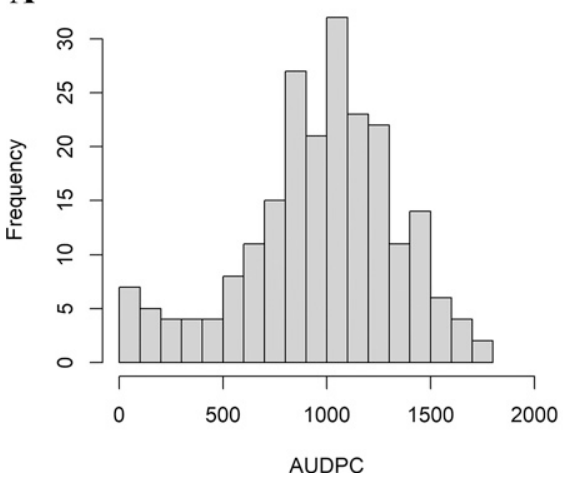

range makes virus management challenging, with the main method being suppressing whitefly populations by the application of insecticides.

Breeding resistant cultivars through conventional methods is time-consuming and requires large-scale phenotyping to identify germplasm materials/accessions with resistance and/or tolerance traits. No cultivars resistant to $\mathrm{CuLCrV}$ were identified during a recent study evaluating $20 \mathrm{C}$. pepo cultivars (Candian et al., 2021), and no sources of resistance to CYSDV or $\mathrm{CuLCrV}$ in summer squash have been identified to date. The germplasm diversity within Cucurbita provides an opportunity for discovery and transfer of novel disease resistance alleles into elite cultivars through hybridization. For example, resistance to various potyviruses has been successfully transferred from $C$. moschata into the $C$. pepo background using interspecific hybridization techniques (Brown et al., 2003; Pachner et al., 2015; Provvidenti, 1997). Similar approaches have been used to transfer resistance to $\mathrm{CYSDV}$ and $\mathrm{CuLCrV}$ from melon accessions into elite germplasm (López-Sesé and Gómez-Guillamón, 2000; Marco et al., 2003; McCreight and Wintermantel, 2011; McCreight et al., 2008).

The objective of this study was to evaluate Cucurbita germplasm for resistance or tolerance to whiteflies and whitefly-transmitted viruses (CuLCrV and CYSDV) in Georgia and Florida. The genotypes identified have the

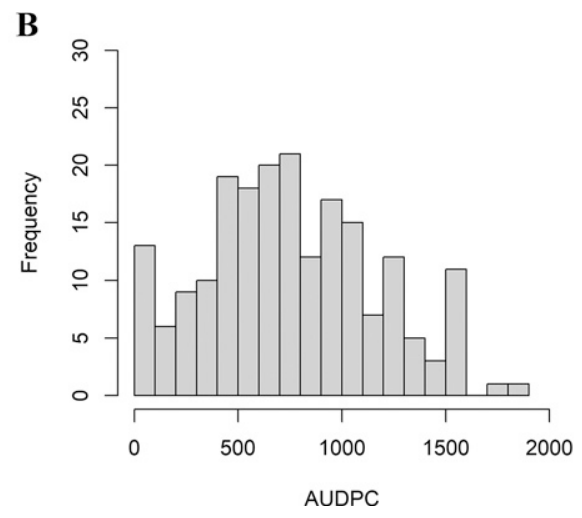

Fig. 1. Frequency distributions of the means from the area under the disease progress curve (AUDPC) calculated from the virus symptom severity for the Cucurbita genotypes evaluated at (A) Tifton, GA, and at (B) Live Oak, FL, in 2019 and 2020. 
potential to be used as sources of resistance in breeding efforts and in genetic studies to elucidate host resistance mechanisms.

\section{Materials and Methods}

Plant material. Plant introduction (PI) accessions from the U.S. Department of Agriculture-Agricultural Research Service germplasm collection, university breeding programs, and commercial companies were selected as potential sources of resistance or tolerance to whiteflies and two whitefly-transmitted viruses, $\mathrm{CuLCrV}$ and CYSDV. In 2019, 166 PIs were selected based on previously described tolerance to silverleaf disorder and aphid-transmitted viruses [Zucchini yellow mosaic virus (ZYMV), Papaya ringspot virus-W (PRSV), Watermelon mosaic virus (WMV), and Cucumber mosaic virus (CMV)]. In Live Oak, FL, two University of Florida C. moschata breeding lines (SS8 and SS12) resistant to Phytophthora Crown Rot and two $C$. pepo cultivars (Enterprise and Grandprize) were added as controls, bringing the total number of genotypes evaluated to 170. These genotypes included 152 C. pepo, 16 C. moschata, and two $C$. ecuadorensis genotypes. In 2020, an additional 30 genotypes were added, including eight $C$. pepo cultivars (Goldprize, Lioness, Lazor, Saffron, Early Golden Crookneck, Yellow Crookneck, CSS-112 and Kakai), one C. moschata cultivar (Butterbush), and one C. maxima cultivar (BigMax) at Live Oak.

Screening in Tifton, GA, included the 166 PIs evaluated in Live Oak and an additional 37 genotypes to increase the amount of genetic diversity and additional control cultivars. These included an additional $29 C$. pepo, two C. moschata, one C. ecuadorensis, three $C$. lundelliana, and two $C$. okeechobeensis subsp. martinezii genotypes. In 2020, 20 bridge lines derived from $C$. pepo $\times C$. moschata crosses were included at both locations

Planting and crop management. Genotypes were evaluated at two locations, Tifton, GA and Live Oak, FL, over 2 years, 2019 and 2020, using a randomized complete block design with three replications of 10 rows or 6 rows per replication in Georgia and Florida, respectively. Each block had four (Florida) or five (Georgia) plants per plot for each genotype. Plants were planted on $15-\mathrm{cm}$ raised beds spaced at $1.82 \mathrm{~m}$ center-to-center with black totally impermeable film (TIF) plastic mulch. An in-row plant spacing of 30 $\mathrm{cm}$ was used in Georgia for a plant population of 17,939 plants/ha. In Florida, the inrow plant spacing used was $60 \mathrm{~cm}$ for a plant population of 8969 plants/ha. At both locations, a single line of drip irrigation was installed in the center of each bed with emitters with $30-\mathrm{cm}$ spacing. In 2019, the experiment was direct-seeded on 20 Aug. at the Hort Hill research farm in Tifton, GA. In 2020 , the experiment was direct-seeded on 14 Aug. at the Tifton Vegetable Park at the University of Georgia Tifton campus in Tifton, GA. Both trials in Live Oak, FL, were
Table 2. Top 10 genotypes for the reduced areas under the disease progress curve (AUDPCs) of group 1 (С. pepo) at Tifton, GA, and Live Oak, FL, in 2019 and 2020. Genotypes common to both locations are in bold.

Group 1

\begin{tabular}{lcllr}
\hline & Tifton, GA & & \multicolumn{2}{c}{ Live Oak, FL } \\
\cline { 5 - 5 } Genotype & AUDPC & & \multicolumn{1}{c}{ Genotypes } & AUDPC \\
\hline PI 176541 & 346.9 & & PI 176546 \\
PI 222786 & 358.2 & PI 442321 & 153.4 \\
PI 234617 & 484.4 & PI 172860 & 154.8 \\
PI 212014 & 494.8 & Early Golden Crookneck ${ }^{z}$ & 160.2 \\
PI 171625 & 498.5 & PI 451849 & 213.9 \\
PI 512749 & 520.0 & PI 182198 & 237.6 \\
PI 442294 & 591.4 & PI 442306 & 245.5 \\
PI 357972 & 599.4 & PI 442294 & 248.1 \\
PI 212012 & 612.6 & PI 172870 & 258.8 \\
PI 176965 & 614.5 & PI 206957 & 275.2 \\
\hline
\end{tabular}

${ }^{\mathrm{z} C o m m e r c i a l ~ c u l t i v a r . ~}$ conducted at the North Florida Research and Education Center, Suwanee Valley. In Florida, 3-week-old squash seedlings were transplanted on 23 Sept. and 22 July for the 2019 and 2020 trials, respectively. Irrigation events were conducted daily to supply $25.4 \mathrm{~mm}$ of water per week, and fertilizer was applied weekly to supply $168 \mathrm{~kg} / \mathrm{ha}$ of nitrogen using 7-0-7 (7N-0P-5.8K; Big Bend Supply Co., Cairo, GA) via fertigation. To manage heavy whitefly population pressure, plants were sprayed as needed with 700 g/ha Flupyradifurone (Sivanto $200 \mathrm{SL}$; Bayer CropScience, Research Triangle Park, NC), 560 g/ha Pyriproxyfen (Knack; Valent, Walnut Creek, $\mathrm{CA}$ ), and $1050 \mathrm{~g} / \mathrm{ha}$ Cyantraniliprole (Exriel; DuPont, Wilmington, DE). All other pest management practices for insects and pathogens followed the University of Georgia and University of Florida recommendations (Dittmar et al., 2020; Taylor, 2018).

Evaluation of germplasm. Viral symptoms were not scored for individual viruses because of the difficulty distinguishing individual virus symptoms. Instead, overall viral symptom severity was evaluated. In Tifton, a scale of 0 to 5 was used: $0=$ no symptoms; $1=1 \%$ to $20 \%$; $2=21 \%$ to $40 \% ; 3=41 \%$ to $60 \% ; 4=61 \%$ to $80 \%$; and $5=81 \%$ to $100 \%$. In 2019 , whole plots were evaluated using this scale starting at
$30 \mathrm{~d}$ after planting (DAP) and evaluated 1 week apart for a total of five data points. In 2020 , individual plants in each plot were evaluated using the same scale starting at 39 DAP and evaluated 1 week apart for a total of five data points. At the Live Oak location in Florida, virus symptom severity data were collected for individual plants in each plot. The virus symptom severity was scored on a scale of $0 \%$ to $100 \%$ scale during both years. In 2019 , data were collected at 17, 24, 38, 45, 59 d after transplanting (DAT). In 2020, data were collected at $35,42,58$, and 64 DAT. The severity score on plants within a plot were averaged to obtain the per-plot virus symptom severity. Per-plot severity data were then used to calculate the area under the disease progress curve (AUDPC) using the midpoint rule (Madden et al., 2007). The AUDPC was calculated as follows:

$$
A U D P C=\sum_{i=2}^{n}\left[\left(y_{i}+y_{i-1}\right) / 2\right]\left(t_{i}-t_{i-1}\right)
$$

where $y_{i}$ is the severity score at $i^{\text {th }}$ evaluation, $t$ is the day of the $i^{t h}$ evaluation, and $n$ is the number of severity evaluations.

At the Tifton location, data were collected for whitefly counts. In 2019, whitefly counts were obtained based on established sampling protocols for adults and immatures on tomato plants with slight modifications (Riley and
Table 3. Top 10 genotypes for reduced area under the disease progress curve (AUDPC) of group 2 (C. moschata, C. okeechobeensis, C. ecuadorensis, C. maxima, and bridge lines) at Tifton, GA, and Live Oak, FL, in 2019 and 2020. Genotypes common to both locations are in bold.

\begin{tabular}{|c|c|c|c|c|c|}
\hline \multicolumn{6}{|c|}{ Group 2} \\
\hline \multicolumn{3}{|c|}{ Tifton, GA } & \multicolumn{3}{|c|}{ Live Oak, FL } \\
\hline Genotype & Species & AUDPC & Genotype & Species & AUDPC \\
\hline UFTP75 & Bridge line & 12.2 & UFTP74 & Bridge line & $0^{\mathrm{y}}$ \\
\hline PI 550692 & C. moschata & 28.4 & UFTP75 & Bridge line & $0^{\mathrm{y}}$ \\
\hline PI 427214 & C. moschata & 31.5 & Butterbush $^{\mathrm{z}}$ & C. moschata & $0^{\mathrm{y}}$ \\
\hline PI 550694 & C. moschata & 62.1 & UFTP66 & Bridge line & $8.8^{\mathrm{y}}$ \\
\hline PI 540899 & C. okeechobeensis & 71.8 & UFTP63 & Bridge line & 18.8 \\
\hline PI 540895 & C. ecuadorensis & 78.6 & PI 634982 & C. moschata & 47.4 \\
\hline UFTP74 & Bridge line & 99.9 & PI 211999 & C. moschata & 58.3 \\
\hline Squash Betternut $900^{z}$ & C. moschata & 109.6 & UFTP76 & Bridge line & 62.2 \\
\hline PI 653064 & C. moschata & 124.7 & PI 550694 & C. moschata & 65.6 \\
\hline PI 550689 & C. moschata & 125.5 & PI 438811 & C. moschata & 69.3 \\
\hline
\end{tabular}

${ }^{\mathrm{z}}$ Commercial cultivar.

${ }^{\mathrm{y}}$ Genotypes were significantly $(P<0.05)$ different from genotypes within the Live Oak, FL, location. 
Srinivasan, 2019). Adult whitefly counts were visually counted from the abaxial surface of one leaf per plant on five plants or maximum available, representing each genotype from each single-row plot at 27 DAP and 34 DAP. Because the whitefly pressure was extremely high, the numbers of adult whiteflies were rounded to the nearest multiple of 50 and/or 100 . In 2020, the adult whitefly counts were obtained at 12 DAP. The underside of the fourth leaf from the meristem per plant in each plot was photographed and later used to count the whiteflies on each leaf. Whitefly counts were performed early during the season because of the presence of hurricane Sally, which resulted in heavy rainfall in early September and ended by 18 Sept. 2020 . The whitefly population did not recover after hurricane Sally or before hurricane Delta in early October. The counts on plants within a plot were averaged to obtain a per-plot whitefly count. The data for each year were analyzed individually.

At Live Oak, plants were also visually rated for squash silverleaf disorder using a scale of $0 \%$ (symptomless) to $100 \%$ (completely silvered) (Paris et al., 1987). For 2019, squash silverleaf data were collected only once at 40 DAT; however, in 2020, data were collected for all dates. To maintain consistency between years, squash silverleaf data closest to 40 DAT in the 2020 experiment (42 DAT) were used for analysis.

Virus quantification. In addition to scoring virus symptom severity, leaf tissue was collected at the Tifton location to quantify $\mathrm{CuLCrV}$ and CYSDV loads/accumulation. In 2019 , leaf tissue was collected from the second leaf from the meristem from five plants per plot and the collected leaf samples were bulked. The total nucleic acids were extracted according to the method developed by Dellaporta et al. (1983). CYSDV was detected using the protocol described by Polston et al. (2008). The CuLCrV was quantified using the protocol described by Gadhave et al. (2020) using SSo Advanced Universal SYBR Green Supermix (Bio-Rad, Hercules, CA) and performed in a CFX96 qPCR thermal cycler (Bio-Rad). The reaction was performed under the following conditions: predegeneration at $95^{\circ} \mathrm{C}$ for $3 \mathrm{~min}$, followed by 35 cycles of $95^{\circ} \mathrm{C}$ for $15 \mathrm{~s}, 55^{\circ} \mathrm{C}$ for $45 \mathrm{~s}$, and $72^{\circ} \mathrm{C}$ for $15 \mathrm{~s}$. At the end of each annealing step, the SYBR Green fluorescent signal was measured. The cycle thresholds were calculated by CFX Maestro Software (Bio-Rad). Every cycle threshold mean value was extrapolated on the corresponding standard curve.

In 2020, leaf tissue was collected from every plant within a plot at 55 DAP. The third leaf from the meristem from every plant within a plot was collected in a $5-\mathrm{mL}$ cryotube and placed in liquid nitrogen until being stored at $-80^{\circ} \mathrm{C}$. Then, each tube was homogenized to create a uniform plot sample. The homogenized samples were separated for DNA and RNA extractions. DNA extractions were performed using the E-Z 96 Plant DNA kit (Omega Bio-Tek, Norcross, GA), and

Table 4. Analysis of variance of whitefly adult counts for 2019 and 2020 in Tifton, GA.

\begin{tabular}{lrrrr}
\hline & df & MS & $F$ value & $\operatorname{Pr}>F$ \\
\hline Replication & 2 & 2019 & & 0.0019 \\
Genotype & 194 & 153,796 & 6.382 & 0.0137 \\
Residuals & 286 & 32,117 & 1.333 & \\
\hline & & 24,098 & & 0.0332 \\
\hline Replication & 2 & 2020 & 3.465 & 0.1560 \\
Genotype & 190 & 2,295 & 1.157 & \\
Residuals & 195 & 767 & & \\
\hline
\end{tabular}

RNA extractions were performed with the E-Z 96 Plant RNA Kit (Omega Bio-Tek) according to the manufacturer's recommendations.

For $\mathrm{CuLCrV}$ quantification, $10 \mathrm{ng}$ of extracted DNA was amplified using 2X GoTaq qPCR Master Mix (Promega, Madison, WI) in a final reaction volume of $10 \mu \mathrm{L}$ on a 384-well plate in a Lightcycler 480 (Roche, Basel, Switzerland) using primers and conditions described by Gautam et al. (2020). A technical replicate was used for every sample. A melting curve analysis was performed to check for primer specificity. The CuLCrV quantity in unknown samples was determined by creating a standard curve using a $10 \mathrm{ng} / \mu \mathrm{L} \mathrm{CuLCrV}$ plasmid and creating a serial dilution to $0.0001 \mathrm{ng} / \mu \mathrm{L}$.

For CYSDV detection, $25 \mathrm{ng}$ of RNA was used to synthesize cDNA following the protocol from the GoScript Reverse Transcription System (Promega). The qPCR was performed in a final volume of $10 \mu \mathrm{L}$ in a 384-well plate using iTaq Universal Probes Supermix (Bio-Rad) run on a Lightcycler 480 (Roche) following the previously described protocol by Gil-Salas et al. (2007). The presence or absence of the virus was determined using a positive control CYSDV plasmid; samples with cycle threshold values less than 35 cycles were considered positive.

Statistics. Genotypes were split into gene pools based on their compatibility with $C$. pepo following Harlan and de Wet (1971) using previous research (Lira-Saade, 1996). For this study, two gene pools were used: $C$. pepo-compatible (group 1) and all other genotypes (group 2). The AUDPC values derived from viral symptom severity were analyzed

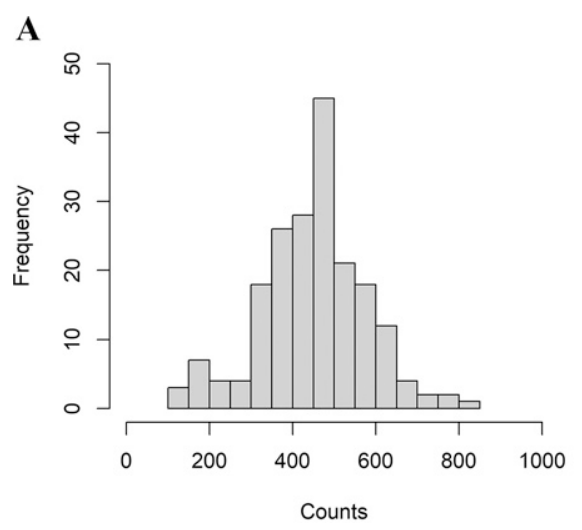

Fig. 2. Frequency distribution of the (A) adult whiteflies counted on the underside of the leaves of the genotypes at Tifton, GA, in 2019 and of the (B) silverleaf disorder severity at Live Oak, FL, in 2019 and 2020.

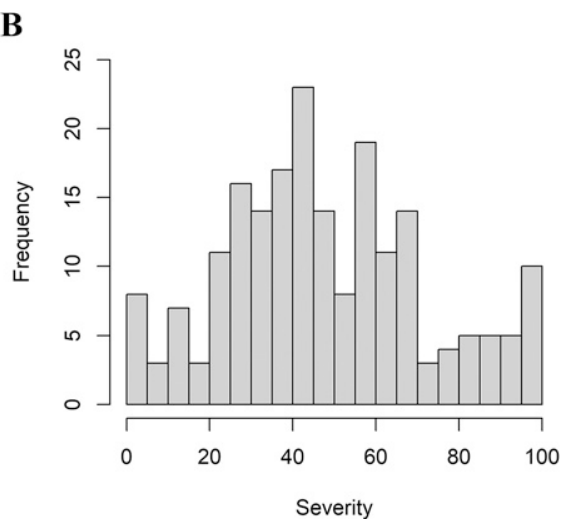

separately for the two locations. A one-way analysis of variance was used to analyze whitefly counts, AUDPC, and CuLCrV accumulation, with genotypes considered fixed effects and year and replications considered random effects. Treatments were considered statistically significant at $P \leq 0.05$. All statistical analyses were performed using $\mathrm{R}$ version 4.0.3 ( $\mathrm{R}$ Core Team, 2020) within RStudio (RStudio Team, 2020). To compare the virus symptom severity of the genotypes between locations, the Tifton data were transformed from the scale of 0 to 5 to a scale of $0 \%$ to $100 \%$ by $Y=(x-x \min ) \div(x \max ) \times$ 100 using midpoints to minimize overestimation (Chiang et al., 2017). Spearman rank correlations were used to compare between years within locations and across locations.

\section{Results}

Evaluation of symptom severity. Symptoms typical of $\mathrm{CuLCrV}$ and CYSDV, including chlorosis, mosaic, mottling, brittle leaves, upward rolling of leaves, and stunting, were present at both locations. Genotypic differences $(P<0.05)$ for AUDPC were observed at both locations (Table 1). The disease symptom severity distributions at both locations (years combined) had relatively normal distributions based on the ShapiroWilks test $(P>0.01)$ (Fig. 1). Disease symptom severity was higher $(P<0.05)$ for $C$. pepo entries (group 1) than for all other entries (group 2) (data not shown). $C$. moschata had significantly $(P<0.05)$ lower symptom severity compared with the other species tested, whereas the other species did

B

(1)

. 
Table 5. Top 10 genotypes for reduced whitefly adult counts in group 1 (C. pepo) and group 2 (C. moschata, C. okeechobeensis, C. ecuadorensis, C. maxima, and bridge lines) at Tifton, GA, in 2019. Genotypes common to visual disease severity are in bold.

Tifton, GA

\begin{tabular}{|c|c|c|c|c|}
\hline \multicolumn{2}{|c|}{ Group 1} & \multicolumn{3}{|c|}{ Group 2} \\
\hline PI 204693 & 150 & PI 540900 & C. okeechobeensis & 100 \\
\hline PI 282486 & 170 & PI 550690 & C. moschata & 150 \\
\hline PI 458731 & 210 & PI 550694 & C. moschata & 163 \\
\hline PI 177373 & 230 & PI 550692 & C. moschata & 188 \\
\hline PI 438700 & 263 & SQUASH BETTERNUT $900^{\mathrm{Z}}$ & C. moschata & 188 \\
\hline PI 234616 & 304 & PI 634982 & C. moschata & 240 \\
\hline PI 181944 & 310 & PI 438579 & C. moschata & 300 \\
\hline
\end{tabular}

${ }^{\overline{\mathrm{z}} \text { Commercial cultivar. }}$

not significantly differ from one another (data not shown). There was one common $C$. pepo genotype, PI 442294, in the top 10 performers between the two locations (Table 2). The C. pepo genotypes in the top 10 were not significantly $(P>0.05)$ different from each other; however, they were significantly better than the bottom $75 \%$ of the genotypes (data not shown). Within the top group, three genotypes identified, C. moschata (PI 550694), and two bridge lines (UFTP74 and UFTP75) were common across locations (Table 3). These two common bridge lines, UFTP74 and UFTP75, outperformed $(P<0.05)$ the other bridge lines for viral disease symptoms.

Whitefly evaluation. The genotype effect on whiteflies counted had significant $(P<$ 0.05 ) differences in 2019, but not in 2020 (Table 4). The distribution of the genotypes in 2019 had a Shapiro-Wilks W of $0.986(P=$ $0.047)$ and was considered normally distributed (Fig. 2A). The two groups were not statistically different from each other in 2019 (Table 5). However, there were significant $(P<0.05)$ differences between the top 10 genotypes from 2019, with a least significant difference of 117.8 (Table 5).

Significant $(P<0.05)$ genotype and year effects were observed for silverleaf disorder evaluated at Live Oak, FL, in 2019 and 2020 (Table 6). It should be noted that fields were planted in September in 2019 and in July in 2020. The distribution of the silverleaf disorder among genotypes had a Shapiro-Wilks W of $0.977(P<0.01)$ (Fig. 2B). There were significant $(P<0.05)$ differences between the top 10 genotypes in group 2 for silverleaf response, but not the top 10 in group 1 (Table 7). The top 10 from group 2 had four genotypes in common with symptom severity at Live Oak (Table 3), one bridge line, UFTP63, and three C. moschata, PI 550694, PI634982, and PI 211999 (Table 7). There was one $C$. pepo genotype, PI 451849 , with low silverleaf disorder symptoms (Table 7) and low symptom severity at Live Oak, FL (Table 2)

Evaluation of viral load. There was a significant year effect for $\mathrm{CuLCrV}$ quantification, with a significant $(P<0.05)$ difference found between genotypes in 2020 , but not in 2019 (Table 8). The two groups (groups 1 and 2) were significantly $(P<0.05)$ different in 2020 (Table 9). Within group 1, the $C$. pepo genotypes were not significantly different from each other. Within group 2, C. moschata had a significantly $(P<0.05)$ lower viral load for CuLCrV than the other species within the group (data not shown). Five C. moschata genotypes, PI 550689, Squash Betternut 900, PI 550692, PI 653064, and PI 550694, and one C. ecuadorensis, PI 540895 , had low viral symptom severity at Tifton (Table 3 ) and also performed in the top 10 for reduced $\mathrm{CuLCrV}$ viral load (Table 9). One $C$. pepo genotype, PI 171625, had both reduced $\mathrm{CuLCrV}$ viral load (Table 9) and low viral symptom severity (Table 2 ).

In $2019,2 \%$ of genotypes tested positive for CYSDV in all replications, whereas $72 \%$ tested positive for all replications in 2020 . Intermediate resistance might exist in genotypes that test negative for CYSDV in at least one of the three replications, with $53 \%$ and $26 \%$ performing in this manner in 2019 and 2020 , respectively. The best-performing genotypes tested negative for CYSDV in all replicates. In $2019,45 \%$ of the genotypes tested negative for the presence of CYSDV, but this decreased to just $2 \%$ of the genotypes in 2020. Only one of the top 10 performing $C$. moschata and $C$. pepo tested negative in both 2019 and 2020, PI 483345 and PI 507882, respectively. Additionally, one C. ecuadorensis (PI 390455) and one C. okeechobeensis (PI 540900) tested negative in both years.

\section{Discussion}

Cucurbita genotypes were evaluated for virus symptom severity in the field in two southeastern U.S. locations (Tifton, GA and Live Oak, FL) in 2019 and 2020. There was one C. moschata genotype, PI 550694, and two bridge lines (UFTP74 and UFTP75) that had low symptom severity in both locations. According to the Germplasm Resources Information Network (www.ars-grin.gov/ npgs), this PI originated from the Cornell University breeding program and is also resistant to silverleaf disorder (WesselBeaver, 1997). The UFTP74 and UFTP75 are selections from the University of Florida cucurbit breeding program with parentage including $C$. lundeliana, C. okeechobeensis, and open pollinated accessions of $C$. moschata and $C$. pepo. Interestingly, two $C$. moschata cultivars, one hybrid (Squash Betternut 900) and one heirloom (Butterbush), were among the top five genotypes for reduced symptom severity. However, they were only evaluated at one location. These cultivars provide elite $C$. moschata sources for introgression of virus resistance into $C$. pepo. One genotype of $C$. pepo (PI 442294) was one of the top performers for reduced symptom severity at both Tifton and Live Oak. This genotype is a landrace originating from Guanajuato in Mexico that had been previously identified as resistant to silverleaf disorder (Wessel-Beaver, 1997). At the Live Oak location, an heirloom cultivar, Early Golden Crookneck, performed in the top five. Unfortunately, this cultivar was not evaluated in Tifton and was not tested for viral load to verify potential resistance.

Viral load was only evaluated at the Tifton location. The viral load for $\mathrm{CuLCrV}$ in $C$. moschata was lower than that of the other species tested, with the best $C$. pepo genotypes having viral loads 10-time to 100-times higher than the best $C$. moschata genotypes. The four C. moschata genotypes, PI 550694, PI 550692, Squash Betternut 900, and PI 653064 , common across lower viral symptom severity and lower whitefly counts also performed in the top 10 for reduced $\mathrm{CuLCrV}$ load. This indicated that commercial breeding

Table 6. Analysis of variance of silverleaf disorder in Live Oak, FL, in 2019 and 2020.

\begin{tabular}{lrrrr}
\hline & df & \multicolumn{1}{c}{ MS } & $F$ value & Pr $>F$ \\
\hline Year & 1 & 28,563 & 54.491 & $<0.0001$ \\
Replication & 2 & 368 & 0.702 & 0.4960 \\
Year $\times$ genotype & 169 & 808 & 1.542 & $<0.0001$ \\
Genotype & 199 & 2,716 & 5.181 & $<0.0001$ \\
Residuals & 733 & 524 & & \\
\hline
\end{tabular}


Table 7. The top 10 genotypes for reduced silverleaf disorder severity in group 1 (C. pepo) and group 2 (C. moschata, C. okeechobeensis, C. ecuadorensis, C. maxima, and bridge lines) at Live Oak, FL, with 2019 and 2020 combined. Genotypes common to visual disease severity are in bold.

Live Oak, FL

\begin{tabular}{lccccc}
\hline & Group 1 & & & \multicolumn{2}{c}{ Group 2 } \\
\cline { 5 - 6 } Genotype & Silverleaf & & Genotype & Species & Silverleaf \\
\hline PI 614685 & 0 & & UFTP63 & Bridge line & $0^{*}$ \\
PI 614688 & 5.6 & & PI 427214 & C. moschata & $0^{*}$ \\
PI 368615 & 6.3 & & PI 550689 & C. moschata & $0^{*}$ \\
PI 174188 & 9.4 & & PI 550692 & C. moschata & $0^{*}$ \\
PI 176961 & 12.5 & & PI 550694 & C. moschata & $0^{*}$ \\
PI 357967 & 12.5 & & PI 634982 & C. moschata & $0^{*}$ \\
PI 451849 & 12.5 & & PI 550690 & C. moschata & $1.1^{*}$ \\
PI 368595 & 12.8 & & PI 211999 & C. moschata & 27.1 \\
PI 212000 & 12.8 & & PI 483345 & C. moschata & 31.3 \\
PI 165047 & 13.5 & PI 653064 & C. moschata & 35.4 \\
\hline
\end{tabular}

*Indicates genotypes significantly $(P<0.05)$ different from genotypes within group 2 .

companies have resistance in their breeding pipelines and can be used to create resistant C. pepo. One C. pepo, PI 171625, was in the top 10 for reduced virus symptom severity and $\mathrm{CuLCrV}$ viral load, and it has been previously identified as a source of resistance to CMV (Lebeda and Kristkova, 1996). It is important to note the lowest viral load found in a $C$. pepo, PI 482592, was seven-fold higher than the viral load found in $C$. moschata, PI 211999, which was at the bottom of the top 10 from group 2 (Table 9). With these higher viral levels detected in the plants, it is difficult to describe any C. pepo evaluated here as resistant to $\mathrm{CuLCrV}$; however, the C. pepo with a low AUDPC but a high viral load could be considered tolerant. The impact of whitefly-transmitted viruses on yield was not evaluated. Further evaluation of yield components of the potentially tolerant $C$. pepo identified in this study should shed light on their utility in breeding programs.

The lack of resistance to $\mathrm{CuLCrV}$ in $C$. pepo in the present study is in agreement with findings by Candian et al. (2021), who evaluated commercial $C$. pepo cultivars. Importantly, it is also in agreement with the results of Hagen et al. (2008), who used agroinoculation. The latter is important because it provides an inoculation method for the study of $\mathrm{CuLCrV}$ independent of the use of whiteflies in controlled or field conditions.

The incidence of CYSDV increased from 2019 to 2020 . This could have been because of an increase in inoculum in the whitefly population over time. Kavalappara et al. (2021a) detected an increase in the presence of CYSDV in cucurbit crops in Georgia in

Table 8. Analysis of variance of CuLCrV viral load $(f \mathrm{~g})$ in 2019 and 2020 at Tifton, GA.

\begin{tabular}{|c|c|c|c|c|}
\hline & df & MS & $F$ value & $\operatorname{Pr}>F$ \\
\hline \multicolumn{5}{|c|}{2019} \\
\hline Replication & 2 & $2.85 \mathrm{E}+15$ & 1.065 & 0.346 \\
\hline Genotype & 195 & $2.62 \mathrm{E}+15$ & 0.977 & 0.569 \\
\hline Residuals & 322 & $2.68 \mathrm{E}+15$ & & \\
\hline \multicolumn{5}{|c|}{2020} \\
\hline Replication & 2 & $4.27 \mathrm{E}+10$ & 2.6 & 0.0759 \\
\hline Genotype & 215 & $4.06 \mathrm{E}+13$ & 2.478 & $<0.0001$ \\
\hline Residuals & 297 & $1.64 \mathrm{E}+10$ & & \\
\hline
\end{tabular}

second year of the present study. Two of these bridge lines, UFTP74 and UFTP75, outperformed the rest for viral symptom severity, with AUDPCs of 99 and 12 at Tifton and a score of 0 for both at Live Oak (Table 3), and had reduced $\mathrm{CuLCrV}$ loads of $3641 \mathrm{fg}$ and $2989 \mathrm{fg}$, respectively. This provides a promising path for introgression of resistance from C. moschata to C. pepo.

There was no significant difference between group 1 (C. pepo) and group 2 (all other species) (data not shown) for adult whitefly counts or silverleaf disorder. This lack of difference between species may be because of the wide host range of whiteflies (Oliveira et al., 2001). Within group 2, three C. moschata genotypes, PI 550694, PI 550692, and PI 653064, commonly had low viral symptom severity at Tifton (Table 3 ) and whitefly counts (Table 5). In addition, PI 211999, PI 550690, PI 550692, PI 550694, PI 634982, and PI 653064 commonly had both silverleaf resistance and low whitefly counts. These results support previous findings of high resistance to silverleaf disorder in PI 211999, PI 550690, PI 550692, and PI 550694 (Wessel-Beaver 1997). However, PI 653064 (Nigerian Local) has been widely used as a source of resistance to several viruses, including ZYMV, PRSV, WMV, CMV (Brown et al., 2003; Gilbert-Albertini et al., 1993; Miranda-Vélez, and Wessel-Beaver,2019; Provvidenti, 1997), and, recently, Tomato leaf curl new Delhi virus (Sáez et al., 2016). Hybrid cultivar Squash Betternut 900 was in the top 10 genotypes for reduced whitefly counts. One C. pepo, PI 172860 , performed in the top 10 for reduced whitefly counts collected in Tifton and virus symptom severity at Live Oak. Although significant differences between genotypes were identified for whitefly counts, it is important to note the best genotype had 150 whiteflies on one leaf. Whitefly resistance and nonpreference have been identified in tomato, with the production of flavonoids conferring the resistant response (Yao et al., 2019). The ability of the whitefly to detoxify plant toxins could explain the difficulty in breeding resistance in plants (Xia et al., 2021). Transgenic methods have successfully overcome the defenses of the whitefly (Ibrahim et al., 2017; Thakur et al., 2014; Xia et al., 2021).

One limitation of the current study was the uneven experimental design between locations and years. Despite this limitation, similar top-performing genotypes were identified at both locations across all traits. Additionally, the virus severity phenotype might include plant responses that are not only specific to the Begomovirus ( $\mathrm{CuLCrV}$ ) and $\mathrm{Cri}$ nivirus (CYSDV) and might have broader resistance that was not tested. This ignored any potential interactions arising from mixed virus infection, which has been identified in other cucurbits infected with multiple viruses (Gautam et al., 2020; Gil-Salas et al., 2012; Zeng et al., 2007). For watermelon, it has been shown that WMV suppresses CYSDV (Domingo-Calap, et al., 2021). For cucumber, interactions between CCYV and CYSDV 
Table 9. Top 10 genotypes for reduced CuLCrV viral load ( $f \mathrm{~g})$ in group $1(C$. pepo) and group $2(C$. moschata, C. okeechobeensis, C. ecuadorensis, C. maxima, and bridge lines) at Tifton, GA, in 2020. Genotypes common to visual disease severity at Tifton, GA, are in bold.

\begin{tabular}{|c|c|c|c|c|}
\hline \multicolumn{5}{|c|}{ Tifton, GA } \\
\hline \multicolumn{2}{|c|}{ Group 1} & \multicolumn{3}{|c|}{ Group 2} \\
\hline Genotype & Concn $(f \mathrm{~g})$ & Genotype & Species & Conen $(f g)$ \\
\hline PI 482592 & 21,987 & PI 550689 & C. moschata & 87 \\
\hline PI 442311 & 22,043 & PI 540895 & C. ecuadorensis & 192 \\
\hline PI 420328 & 24,437 & PI 483345 & C. moschata & 200 \\
\hline PI 379310 & 27,455 & SQUASH BETTERNUT $900^{\mathrm{Z}}$ & C. moschata & 234 \\
\hline PI 227237 & 42,489 & PI 550692 & C. moschata & 354 \\
\hline PI 458731 & 53,614 & PI 653064 & C. moschata & 428 \\
\hline PI 171625 & 55,400 & PI 550694 & C. moschata & 1,049 \\
\hline Ames 26619 & 60,230 & PI 634982 & C. moschata & 2,624 \\
\hline PI 442791 & 61,551 & PI 540900 & C. okeechobeensis & 2,770 \\
\hline PI 212060 & 62,062 & PI 211999 & C. moschata & 2,987 \\
\hline
\end{tabular}

${ }^{\mathrm{z}}$ Commercial cultivar.

have been shown to increase transmission efficiency of both viruses but to decrease virus titers (Orfanidou et al., 2021). For squash, a mixed infection of $\mathrm{CuLCrV}$ and CYSDV leads to increased symptom severity and decreased the CYSDV viral load (Gautam et al., 2020). It is important to further evaluate these genotypes in depth to determine their phenotypic reaction to $\mathrm{CuLCrV}$, CYSDV, and the newly identified CCYV to confirm the findings of this study.

\section{Conclusion}

This study identified several genotypes of C. moschata for plant breeders to select from to initiate their $\mathrm{CuLCrV}$ and CYSDV resistance breeding programs. Based on this study, the species C. moschata is currently the best source of resistance to these viruses. Specifically, five genotypes of C. moschata, PI 550689, PI 550692, PI 550694, PI 653064, and Squash Betternut 900, performed well. In addition, one C. ecuadorensis, PI 540895, performed well with reduced viral load and virus symptom severity. Two breeding lines, UFTP74 and UFTP75, had the highest viral resistance among the bridge lines evaluated and present a viable option for quicker introgression of resistance into the C. pepo genetic background. Potentially, two $C$. pepo genotypes, PI 442294 and PI 171625, are worth exploring; however, when compared with $C$. moschata, their resistance was much lower in C. pepo. The results of this study were in line with those of previous evaluations of Cucurbita (Candian et al., 2021). The genotypes identified here can contribute to future studies to elucidate the molecular basis of host resistance and breed resistant cultivars for growers.

\section{Literature Cited}

Adkins, S., S.E. Webb, D. Achor, P. Roberts, and C.A. Baker. 2007. Identification and characterization of a novel whitefly-transmitted member of the family Potyviridae isolated from cucurbits in Florida. Phytopathology 97:145-154, https://doi.org/10.1094/PHYTO-97-2-0145.

Adkins, S., J.E. Polston, and W.W. Turechek. 2009. Cucurbit leaf crumple virus identified in common bean in Florida. Plant Dis. 93:320, https://doi.org/10.1094/PDIS-93-3-0320B.

Adkins, S., C.G. Webster, C.S. Kousik, S.E. Webb, P.D. Roberts, P.A. Stansly, and W.W. Turechek. 2011. Ecology and management of whitefly-transmitted viruses of vegetable crops in Florida. Virus Res. 159:110-114, https:// doi.org/10.1016/j.virusres.2011.04.016.

Aguilar, J.M., M. Franco, C.F. Marco, B. Berdiales, E. Rodriguez-Cerezo, V. Truniger, and M.A. Aranda. 2003. Further variability within the genus Crinivirus, as revealed by determination of the complete RNA genome sequence of Cucurbit yellow stunting disorder virus. J. Gen. Virol. 84:2555-2564, https://doi.org/10.1099/ vir.0.19209-0.

Akad, F., S. Webb, T.W. Nyoike, O.E. Liburd, W. Turechek, S. Adkins, and J.E. Polston. 2008. Detection of Cucurbit leaf crumple virus in Florida cucurbits. Plant Dis. 92:648, https:// doi.org/10.1094/PDIS-92-4-0648C.

Brown, R.N., A. Bolanos-Herrera, J.R. Myers, and M. Miller Jahn. 2003. Inheritance of resistance to four cucurbit viruses in Cucurbita moschata. Euphytica 129:253-258, https://doi.org/10.1023/ A:1022224327064.

Candian, J.S., T. Coolong, B. Dutta, R. Srinivasan, A. Sparks, A. Barman, and A.L.B.R. da Silva. 2021. Yellow squash and zucchini cultivar selection for resistance to Cucurbit leaf crumple virus in the southeastern United States. HortTechnology 31:504-513, https://doi.org/ 10.21273/HORTTECH04877-21.

Chiang, K.S., H. Liu, and C.H. Bock. 2017. A discussion on disease severity index values. Part 1: Warning on inherent errors and suggestions to maximize accuracy. Ann. App. Bio. 171:139154, https://doi.org/10.1111/aab.12362.

Czosnek, H., M. Ghanim, and M. Ghanim. 2002. The circulative pathway of Begomoviruses in the whitefly vector Bemisia tabaci - insights from studies with Tomato yellow leaf curl virus. Ann. Appl. Biol. 140:215-231, https:// doi.org/10.1111/j.1744-7348.2002.tb00175.x.

Dellaporta, S., J. Wood, and J.B. Hicks. 1983. A plant DNA minipreparation: Version II. Plant Mol. Biol. Rpt. 1:19-21, https://doi.org/ 10.1007/BF02712670.

Dittmar, P.J., J.H. Freeman, M.L. Paret, and H.A. Smith. 2020. 2020-2021 Vegetable Production Handbook: EDIS. 18 May 2021. <https:// edis.ifas.ufl.edu/pdf/CV/CV29200.pdf>.

Domingo-Calap, M.L., O. Chase, M. Estapé, A.B. Moreno, and J.J. López-Moya. 2021. The P1 protein of watermelon mosaic virus compromises the activity as RNA silencing suppressor of the P25 protein of cucurbit yellow stunting disorder virus. Front. Microbiol. 12:645530, https://doi.org/10.3389/fmicb.2021.645530.

Florida Department of Agriculture. 2021. Florida agriculture overview and statistics. Florida Department of Agriculture and Consumer Services. 18 May 2021. <https://www.fdacs.gov/AgricultureIndustry/Florida-Agriculture-Overview-andStatistics $>$.

Gadhave, K.R., B. Dutta, T. Coolong, N.A. Sparks, S. Adkins, and R. Srinivasan. 2018. First report of Cucurbit yellow stunting disorder virus in cucurbits in Georgia, United States. Plant Health Prog. 19:1, 9-10, https://doi.org/10.1094/PHP03-17-0016-BR.

Gadhave, K.R., S. Gautam, B. Dutta, T. Coolong, S. Adkins, and R. Srinivasan. 2020. Low frequency of horizontal and vertical transmission of Cucurbit leaf crumple virus in whitefly Bemisia tabaci Gennadius. Phtyopathology. 16, https://doi.org/10.1094/PHYTO-09-19-0337-R.

Gautam, S., K.R. Gadhave, J.W. Buck, B. Dutta, T. Coolong, S. Adkins, and R. Srinivasan. 2020. Virus-virus interactions in a plant host and in a hemipteran vector: Implications for vector fitness and virus epidemics. Virus Res. 286:198069, https://doi.org/10.1016/j.virusres. 2020.198069 .

Gilbert-Albertini, F., H. Lecoq, M. Pitrat, and J.L. Nicolet. 1993. Resistance of Cucurbita moschata to Watermelon mosaic virus type 2 and its genetic relation to resistance to Zucchini yellow mosaic virus. Euphytica 69:231-237, https://doi.org/10.1007/BF00022369.

Gil-Salas, F.M., J. Morris, A. Coyler, G. Budge, N. Boonham, I.M. Cuadrado, and D. Janssen. 2007. Development of real-time RT-PCR assays for the detection of Cucumber vein yellowing virus (CVYV) and Cucurbit yellow stunting disorder virus (CYSDV) in the whitefly vector Bemisia tabaci. J. Virol. Methods 146:45-51, https://doi.org/10.1016/j.jviromet. 2007.05.032.

Gil-Salas, F.M., J. Peters, N. Boonham, I. Cuadrado, and D. Janssen. 2012. Co-infection with Cucumber vein yellowing virus and Cucurbit yellow stunting disorder virus leading to synergism in cucumber. Plant Pathol. 61:468-478, https:// doi.org/10.1111/j.1365-3059.2011.02545.x.

Hagen, C., M. Rojas, M. Sudarshana, B. Xoconostle-Cazares, E. Natwick, T. Turini, and R. Gilbertson. 2008. Biology and molecular characterization of Cucurbit leaf crumple virus, an emergent cucurbit-infecting Begomovirus in the Imperial Valley of California. Plant Dis. 92:781-793, https://doi.org/10.1094/ PDIS-92-5-0781.

Harlan, J.R. and J.M.J. de Wet. 1971. Toward a rational classification of cultivated plants. Taxon 20:509-517, https://doi.org/10.2307/ 1218252.

Herrington, M., D. Byth, D. Teakle, and P. Brown. 1989. Inheritance of resistance to Papaya ringspot virus type $\mathrm{W}$ in hybrids between Cucurbita ecuadorensis and C. maxima. Aust. J. Exp. Agr. 29:253-259, https:// doi.org/10.1071/EA9890253.

Ibrahim, A.B., T.R. Monteiro, G.B. Cabral, and F.J.L. Aragão. 2017. RNAi-mediated resistance to whitefly (Bemisia tabaci) in genetically engineered lettuce (Lactuca sativa). Transgenic Res. 26:613-624, https://doi.org/ 10.1007/s11248-017-0035-0.

Jailani, A.A.K., F. Iriarte, B. Hochmuth, S.M. Willis, M. Warren, K. Dey, M. Velez-Climent, J. McVay, S. Bag, and M.L. Paret. 2021. First report of cucurbit chlorotic yellows virus affecting watermelon in USA. Plant Dis., https://doi.org/10.1094/PDIS-03-21-0639-PDN. 
Kavalappara, S.R., H. Milner, N.C. Konakalla, K. Morgan, A.N. Sparks, C. McGregor, A.K. Culbreath, W.M. Wintermantel, and S. Bag. 2021a. High throughput sequencing-aided survey reveals widespread mixed infections of whitefly-transmitted viruses in cucurbits in Georgia, USA. Viruses 13:988, https://doi.org/ 10.3390/v13060988.

Kavalappara, S.R., H. Milner, A.N. Sparks, C. McGregor, W.M. Wintermantel, and S. Bag. 2021b. First report of Cucurbit chlorotic yellows virus in association with other whiteflytransmitted viruses in squash (Cucurbita pepo) in Georgia. Plant Dis.; Epub ahead of print, https:// doi.org/10.1094/PDIS-11-20-2429-PDN.

Larsen, R. and K. Kmiecik. 2010. First report of Cucurbit leaf crumple virus in snap bean in Georgia; Proceedings of the Phytopathology, 2010 American Phytopathological Society Annual Meeting; Charlotte, NC, USA. 7-11 Aug. 2010; p. S68.

Lebeda, A. and E. Kristkova. 1996. Resistance in Cucurbita pepo and Cucurbita maxima germplasms to cucumber mosaic virus. Genet. Resources Crop Evol. 43:461-469, https:// doi.org/10.1007/BF00123736.

Lira-Saade, R. 1996. Estudios taxonomicos y ecogeographicos de las Cucurbitaceae latinoamericanas de importancia economica. Systematic and Ecogeographic Studies on Crop Gene pools. No 9. IPGRI, Rome, Italy.

Little, E.L., P.M. Brannen, G. Jagdale, B. Dutta, and J.H. Brock. 2019. 2017 Georgia plant disease loss estimates. University of Georgia Extension. 10 May 2021. <https://extension.uga.edu/ publications/detail.html?number $=\mathrm{AP} 102-10>$.

Little, E.L., P.M. Brannen, G. Jagdale, B. Dutta, and J.H. Brock. 2020. 2018 Georgia plant disease loss estimates. University of Georgia Extension. 10 May 2021. <https://extension.uga.edu/ publications/detail.html?number=AP102-11>.

López-Sesé, A.I. and M.L. Gómez-Guillamón. 2000. Resistance to Cucurbit yellowing stunting disorder virus (CYSDV) in Cucumis melo $\mathrm{L}$. HortScience 35:110-113, https://doi.org/10.21273/ HORTSCI.35.1.110.

Madden, L.V., G. Hughes, and F. van den Bosch. 2007. The study of plant disease epidemics. American Phytopathological Society, St. Paul, MN, https://doi.org/10.1094/9780890545058.

Marco, C.F., J.M. Aguilar, J. Abad, M.L. GómezGuillamón, and M.A. Aranda. 2003. Melon resistance to Cucurbit yellow stunting disorder virus is characterized by reduced virus accumulation. Phytopathology 93:844-852, https:// doi.org/10.1094/PHYTO.2003.93.7.844.

Marco, C.F. and M.A. Aranda. 2005. Genetic diversity of a natural population of Cucurbit yellow stunting disorder virus. J. Gen. Virol. 86: 815-822, https://doi.org/10.1099/vir.0.80584-0.

Martín-Hernández, A.D. and B. Picó. 2021. Natural resistances to viruses in Cucurbits. Agronomy (Basel) 11:23, https://doi.org/10.3390/ agronomy11010023.

McCreight, J.D., H.Y. Liu, and T.A. Turini. 2008. Genetic resistance to Cucurbit leaf crumple virus in Melon. HortScience 43:122, https:// doi.org/10.21273/HORTSCI.43.1.122.

McCreight, J.D. and W.M. Wintermantel. 2011. Genetic resistance in Melon PI 313970 to Cucurbit yellow stunting disorder virus. HortScience 46:1582-1587, https://doi.org/10.21273/HORTSCI. 46.12.1582.

Miranda-Vélez, M.A. and L. Wessel-Beaver. 2019. Non-transmission of ZYMV and PRSV through resistant Cucurbita moschata genotypes 'Nigerian Local' and 'Menina'. Rep. Cucurbit Genet. Coop. 42:37-39, https://cucurbit.info/wp-content/ uploads/2020/09/CGC-42_2019_all_final.pdf.
Munger, H.M. and R. Provvidenti. 1987. Inheritance of resistance to ZYMV in Cucurbita moschata. Cucurbit Genet. Coop. 10:80-81.

Nakhla, M.K. and D.P. Maxwell. 1998. Epidemiology and management of tomato yellow leaf curl disease, p. 565-583. In: A. Hadidi, R.K. Khetarpal, H. Koganezawa (eds.). Plant virus disease control. APS Press, St Paul, MN.

Navas-Castillo, J., E. Fiallo-Olivé, and S. Sánchez-Campos. 2011. Emerging virus diseases transmitted by whiteflies. Annu. Rev. Phytopathol. 49:219-248, https://doi.org/10.1146/ annurev-phyto-072910-095235.

Oliveira, M.R.V., T.J. Henneberry, and P. Anderson. 2001. History, current status, and collaborative research projects for Bemisia tabaci. Crop Prot. 20:709-723, https://doi.org/10.1016/S0261-2194 (01)00108-9.

Orfanidou, C., A. Katsiani, L. Papayiannis, N.I. Katis, and V.I. Maliogka. 2021. Interplay of Cucurbit yellow stunting disorder virus with Cucurbit chlorotic yellows virus and transmission drynamics by Bemisia tabaci MED. Plant Dis. 105:416-424, https://doi.org/10.1094/PDIS03-20-0621-RE.

Pachner, M., H.S. Paris, J. Winkler, and T. Lelley. 2015. Phenotypic and marker-assisted pyramiding of genes for resistance to zucchini yellow mosaic virus in oilseed pumpkin (Cucurbita pepo). Plant Breed. 134:121-128, https:// doi.org/10.1111/pbr.12219.

Paris, H.S., H. Nerson, and Y. Burger. 1987. Leaf silvering of Cucurbita. Can. J. Plant Sci. 67:593-598, https://doi.org/10.4141/cjps87-083.

Paris, H.S., S. Cohen, Y. Burger, and R. Yoseph. 1988. Single-gene resistance to Zucchini yellow mosaic virus in Cucurbita moschata. Euphytica 37:27-29, https://doi.org/10.1007/BF00037219.

Paris, H.S. and S. Cohen. 2000. Oligogenic inheritance for resistance to Zucchini yellow mosaic virus in Cucurbita pepo. Ann. Appl. Biol. 136:209-214, https://doi.org/10.1111/j.17447348.2000.tb00027.x.

Polston, J.E., L.L. Hladky, F. Akad, and W.M. Wintermantel. 2008. First report of Cucurbit yellow stunting disorder virus in cucurbits in Florida. Plant Dis. 92:1251, https://doi.org/ 10.1094/PDIS-92-8-1251B.

Provvidenti, R. 1997. New American summer squash cultivars possessing a high level of resistance to a strain of Zucchini yellow mosaic virus from China. Cuc. Genet. Coop. Rep. 20:57-58.

R Core Team. 2020. R: A language and environment for statistical computing. R Foundation for Statistical Computing, Vienna, Austria. $<$ https://www.R-project.org/>.

Robinson, R.W., N.F. Weeden, and R. Provvidenti. 1988. Inheritance of resistance to Zucchini yellow mosaic virus in the interspecific cross Cucurbita maxima $\times$ C. ecuadorensis. Rep. Cucurbit Genet. Coop. 11:74-75.

Romero-Masegosa, J., C. Martínez, E. Aguado, A. García, G. Cebrián, J. Iglesias-Moya, H.S. Paris, and M. Jamilena. 2020. Response of Cucurbita spp. to Tomato leaf curl New Delhi virus inoculation and identification of a dominant source of resistance in Cucurbita moschata. Plant Pathol. 70:206-218, https:// doi.org/10.1111/ppa.13268.

Riley, D.G. and R. Srinivasan. 2019. Integrated management of Tomato yellow leaf curl virus and its whitefly vector in tomato. J. Econ. Entomol. 112:1526-1540, https://doi.org/10.1093/jee/toz051.

RStudio Team. 2020. RStudio: Integrated Development Environment for R. RStudio, PBC, Boston, $\mathrm{MA}<\mathrm{http}: / / \mathrm{www}$.rstudio.com/ $>$.
Rubio, L., Y. Abou-Jawdah, H.X. Lin, and B.W Falk. 2001. Geographically distant isolates of the Crinivirus Cucurbit yellow stunting disorder virus show very low genetic diversity in the coat protein gene. J. Gen. Virol. 82:929-933, https:// doi.org/10.1099/0022-1317-82-4-929.

Sáez, C., C. Martínez, M. Ferriol, S. Manzano, L. Velasco, M. Jamilena, C. López, and B. Picó. 2016. Resistance to Tomato leaf curl New Delhi virus in Cucurbita spp. Ann. Appl. Biol. 169:91-105, https://doi.org/10.1111/aab.12283.

Stubbs, K. 2020. Georgia Farm Gate Value Report 2019. The University of Georgia Center for Agribusiness and Economic Development. AR-20-01. 18 May 2021. <https://caed.uga.edu/ content/dam/caes-subsite/caed/publications/annualreports-farm-gate-value-reports $/ 2019 \% 20 \mathrm{Farm} \%$ 20Gate\%20Report.pdf $>$.

Taylor, M.D. 2018. Georgia pest management handbook. University of Georgia Cooperative Extension Service Bul. 28.

Thakur, N., S.K. Upadhyay, P.C. Verma, K. Chandrashekar, R. Tuli, and P.K. Singh. 2014. Enhanced whitefly resistance in transgenic tobacco plants expressing double stranded RNA of v-ATPase A gene. PLoS One 9(3):e87235, https://doi.org/10.1371/journal.pone.0087235.

USDA. 2020. Vegetables 2019 Summary. United States Department of Agriculture: National Agricultural Statistics Service. 18 May 2021. <https:// www.nass.usda.gov/Publications/Todays_Reports/ reports/vegean20.pdf>

Washek, R.L. and H.M. Munger. 1983. Hybridization of Cucurbita pepo with disease resistant Cucurbita species. Cucurbita Genet. Coop. 6:92.

Wessel-Beaver, L. 1997. Screening for silverleaf resistance in Cucurbita. Rep. Cucurbit Genet. Coop. 20:54-56.

Wessel-Beaver, L. 2005. Cultivar and germplasm release. Release of 'Soler' tropical pumpkin. J. Agr. Univ. P. R. 89:263-266, https://doi.org/ 10.46429/jaupr.v89i3-4.1047.

Whitaker, T.W. and R.W. Robinson. 1986. Squash breeding, p. 204-242. In: M.J. Basset (ed.). Breeding vegetable crops. AVI Publ. Co., Westport, CT.

Wintermantel, W.M., L.L. Hladky, A.A. Cortez, and E.T. Natwick. 2009. A new expanded host range of Cucurbit yellow stunting disorder virus includes three agricultural crops. Plant Dis. 93:685-690, https://doi.org/10.1094/PDIS93-7-0685.

Witte, A.K., R. Sickha, P. Mester, S. Fister, D. Schoder, and P. Rossmanith. 2020. Essential role of polymerases for assay performance Impact of polymerase replacement in a wellestablished assay. Biomol. Detect. Quantif. 16:12-20, https://doi.org/10.1016/j.bdq.2018.10. 002.

Xia, J., Z. Guo, Z. Yang, H. Han, S. Wang, H. Xu, X. Yang, F. Yang, Q. Wu, W. Xie, X. Zhou, W. Dermauw, T.C.J. Turlings, and Y. Zhang. 2021. Whitefly hijacks a plant detoxification gene that neutralizes plant toxins. Cell 184:1-13, https:// doi.org/10.1016/j.cell.2021.02.014.

Yao, Q., Z. Peng, H. Tong, F. Yang, G. Xing, L. Wang, J. Zheng, Y. Zhang, and Q. Su. 2019. Tomato plant flavonoids increase whitefly resistance and reduce spread of Tomato yellow leaf curl virus. J. Eco. Ent. 112:2790-2796, https://doi.org/10.1093/jee/toz199.

Zeng, R., Q. Liao, J. Feng, D. Li, and J. Chen. 2007. Synergy between Cucumber mosaic virus and Zucchini yellow mosaic virus on Cucurbitaceae hosts tested by real-time reverse transcription-polymerase chain reaction. Acta Biochim. Biophys. Sin. (Shanghai) 39:431-437, https:// doi.org/10.1111/j.1745-7270.2007.00292.x. 